\title{
Dynamics of educational, career and life motives of female psychology students in the process of studying at a university
}

\author{
S.T. Dzhaneryan ${ }^{1 *}$, and D.I. Gvozdeva ${ }^{2}$ \\ ${ }^{1}$ Southern Federal University, Rostov-on-Don, Russia \\ ${ }^{2}$ Southern Federal University, Rostov-on-Don, Russia
}

\begin{abstract}
The article presents the results of a research aimed at establishing the dynamics of educational, career, life motives of female students of higher educational institutions studying psychology. The research methods were testing (methods: "Career Anchors" (E. Shane, adaptation and translation by V.Ya. Vinokurov, V.A. Cheeker), "Diagnostics of the motivational structure of a personality" (V.E. Milman), "Humorous phrases test" (HFT) (A.G. Shmelev, A.S. Babina); longitudinal sections method (longitudinal method). As statistical methods for analyzing the results, methods of parametric (multiple linear regression) and nonparametric statistics (Friedman, Wilcoxon tests) were used.
\end{abstract}

\section{A problem statement}

Features of the motivational component are the most important psychological condition for the effective professional activity of a specialist, in which consumers of professional services, employers, and the whole society are interested. The role of this component at the stage of obtaining a professional education by the subject is high, which is reflected in the close attention of researchers, teaching staff of universities to the results of monitoring the dynamics of students' motives, which allows optimizing the process of professional training, giving adequate forecasts about the effectiveness of employment and the implementation of real professional activity by university graduates. To an even greater extent, knowledge about the specifics of students' motives, consolidating their aspirations to master the corresponding profession and to its future implementation in the career and living space, allows specialists of psychological services, curators of student groups to optimize the psychological support of students, and in particular, students in psychology. At the presence of unstable socio-economic conditions of life, the dynamism of the labor market, changeable information flows, constant modifications of higher professional education, the motivational potential of students in psychology requires increased attention, since the psychological well-being of individuals and the quality of life of society as a

\footnotetext{
*Corresponding author: prof-ped.gpa@mail.ru
} 
whole largely depends on the quality of the students' professional training and future activities.

In the works devoted to the disclosure of the content of the psychological support of educational process, a general focus is on promoting the full development and selfdevelopment of the personality (in particular, the student), its self-determination and selfactualization [1-4]. The specificity of psychological support for students varies depending on the course of study.

The psychological support of first-year students is firstly associated with solving the problems of their adaptation [2-7] to the procedural-productive, spatio-temporal, sociopsychological conditions of educational activity, which, being the leading one at this stage of professional development, lays the foundations for the success of real professional activity in the future. The psychological support of students of courses 2-3, which, according to researchers, are crisis [3], is associated with solving the problem of constructive overcoming of students' declining interest in learning and educational motivation, the formation of a professional self-concept, an adequate reassessment of ideals, and an increase in the pragmatic fulfillment of life. For graduate students, the solution of problems of psychological support is carried out in the context of the transition from the student environment to the professional environment. Here, the work with students is intensified for their awareness of the new social situation of development, correlating their own requirements, aspirations and opportunities with the upcoming professional and career line of development, building family life, etc. [3]. At the same time, the entire period of study at the university is considered as a special meaningful period in life, providing the student's identification with the subject of the future profession [8-10]. Therefore, regardless of the stage and content of professional training, there are issues, the solution of which is to assist students' self-determination. This includes, first of all, the students' awareness of their own motives for educational activities in relation to their career motives and broader life orientations.

The analysis of works devoted to the study of the motives of educational activity and the motives of professional career allows drawing the following conclusions.

The students are considered as the most dynamic group of young persons in the sociocultural and intellectual terms which is characterized by a lack of proper experience, instability of self-assessments, excessive claims [11] along with the dominance of material, hedonistic, individualistic values in the mind [12-14].

The subject of an especially active study was the content of the leading educational, career, professional motives of students [15-18]. The emphasis is on the dependence of the content of these motives, in particular, career ones, on the stages and content of the professional orientation of education [19]. Along with this, it is indicated that the educational motive of achievement among female students in psychology [15] is low, there is the dominating educational motive of "getting a diploma" among students in psychology, which indicates the intensity of the unprofessionally oriented tendency among students [16].

From the results of a number of researches, it follows that students have a predominance of career motives of Serving, Integration of lifestyles [16], motives of career achievement [15], which in general, according to scientists, reflects age, gender and professional features of the student youth. This predominance is mostly noted among students of humanitarian specialties, as well as among female students $[16,19]$.

At the same time, educational motives are considered as a focus on its individual aspects dictated by an internal attitude to educational work and not exhausted by the acquisition and assimilation of knowledge [17, 20]. Career motives or career orientations are revealed within the interpretation of career as an internal process of unlocking personal 
potential, where each career orientation includes the content of the employee's self-ideas, including key values, motives, skills that determine the choice and way of career [19].

The relationship between educational, career, professional motives of humanitarian students is noted $[15,16,21]$, which is of a correlation nature. The determining influence of life motives on educational and career motives is separately discussed. The latter include the motives that affect the entire sphere of human life and are expressed in the most general and relevant life tendencies [17]. We believe that the inclusion of life motives in the study agenda in the context of studying the educational and career motives of students seems appropriate for a number of reasons. The main ones are that life motives are not excluded from the context of studying the subject of professional activity, thereby creating the possibility of predicting the development of the employee's personality, which itself can be a factor in the development of activity. The effectiveness of the provision on the interaction of professional and personal factors at all stages of the subject formation is preserved: the personal factor, being formed earlier and being broader than the professional one, has a corrective effect on the professional activity and career of the subject [22, et al.]. The regularities of the subject's formation at different age stages, which is reflected in the specifics of the content of the psychological support of students (e.g. students of the last courses of study), as well as the above statements of researchers about the primary influence of life motives on the educational and career motives of students, are taken into account.

In various researches, the dynamics of the motivational sphere of students is traced according to the results of cross-sections, suggesting the fixation of the severity or hierarchy of substantively similar motives among students of different courses of education. We believe that this tradition should be supplemented with the results of studying students' motives using the longitudinal sections method. This method involves studying the motives of one subject or a group of persons at different stages of their professional training, allowing identification of dynamic patterns of educational, career, life motives and their connectivity.

Based on these provisions, we turned to a longitudinal research of motives - of education, career, life - among university students in Psychology.

\subsection{The objective of the work}

Purpose of research: establishing the dynamics of motives (career, educational, life ones) among female students in psychology in the process of studying at the university.

Subject of research: career, educational and life motives of female students in psychology at different stages of their studies at the university.

Object of research: motives of female students in psychology.

The methodological foundations of this research were the principles of activity and the unity of consciousness and activity (A.N. Leontiev, S.L. Rubinstein); ideas in psychology about the need-motivational-value sphere of the individual as the basis of the individual's life (A.N. Leontiev, D.A. Leontiev, A. Maslow) and professional activity (K.A. Abulkhanova-Slavskaya et al.); provisions on the conditionality of the subject's self-ideas according to the context of own life (V.V. Stolin, L.M. Mitina, S.T. Dzhaneryan); the idea of a motive as an object (real, perceived, imagined, conceivable) of activity, multilaterally comprehended by the subject in the context of own needs (A.N. Leontiev, D.A. Leontiev).

The educational motive is considered by us as the focus of the subject on certain aspects of educational work [17, 20]. A professional career is interpreted here as a professional path inextricably linked with socialization and personality development, at each stage of which the subject realizes own capabilities, ensuring the achievement of results that are significant for the subject [23]. 
Career motives are considered as striving of the subject to realize own capabilities, ensuring the achievement of results being significant for the subject in the conditions of professional activity. The life motives include the ones that affect the entire sphere of the life of a human - a biological individual, a social individual, a personality - and are expressed in the most general and relevant life tendencies.

Research methods: testing (methods: "Career Anchors" (E. Shane, adaptation and translation by V.Ya. Vinokurov, V.A. Cheeker), "Diagnostics of the motivational structure of a personality" (V.E. Milman), "Humorous phrases test" (HFT) (A.G. Shmelev, A.S. Babina); longitudinal sections method (longitudinal method); statistical methods of parametric (multiple linear regression) and nonparametric statistics (Friedman, Wilcoxon tests).

Career motives were studied using the following methodology: "Career Anchors" (E. Shane, adaptation and translation by V.Ya. Vinokurov, V.A. Cheeker), based on the consideration of career as an internal process of unlocking personal potential in the context of the chosen career. The technique allows diagnosing the intensity of the following career motives (orientations): Self-reliance; Stability of the place of residence; Stability of the place of work; Entrepreneurship; Challenge; Professional competence; Management; Serving; Integration of lifestyles. It is widely used when studying the value and motivational sphere of students in psychology [16, 24].

Educational and professional motives were studied using the methodology of "Diagnostics of the personality motivational structure" (V.E. Milman), which makes it possible to diagnose the following educational motives based on the description of educational and professional activities at the university: maintenance of life necessities, comfort, social status, communication, general activity, creative activity, social utility.

The life motives were studied using the "Humorous phrases test" (HFT) (A.G. Shmelev, A.S. Babin), which makes it possible to diagnose the motivational sphere of a person, taking into account the specifics of the needs of a biological, social individual and a personality. The most stable and widespread constructs of everyday consciousness presented in the test include such motives as Aggression-self-defense (self-preservation), Sex, Addictions, Money, Fashion, Career, Family and social well-being, Search for harmony and beauty, striving for Cognition.

Determination of the influence of career and life motives on the educational and professional motives of the subjects was carried out using multiple linear regression analysis as a measure and sign of the directed influence of individual career and life motives on the intensity of the leading educational and professional motive (Table 2).

The multiple linear regression analysis, as well as testing the assumptions about the normality of the distributions of the indicators of interest to us, were performed in the Factor Analysis, Multiple Regression, Descriptive Statistics modules (Shapiro-Wilks Wtest, Kolmogorov-Smirnov normality criterion for general totalities with Lilliefors probabilities adjusted for sample observations) of Tibco statistica software 13.3.

Friedman and Wilcoxon criteria were used to identify the dominant motive in each of the career, educational, life motives of female students.

Sample characteristic: at the first stage (2018), female students of courses 1-2 in bachelor degree in psychology (52 persons) were involved in the research; at the second stage (2020), the same students receiving bachelor education were in courses 3-4 (43 persons). The age of the female students in the sample ranges from 18 to 24 years old.

\section{Results of the research}

The results of the research of motives among female students of courses 1-2 and 3-4 allow us to conclude the following. As female students grow up professionally, the range of their 
dominant career and life motives changes: the list of the former ones is narrowing, and the list of the latter ones is expanding. The leading educational and professional motives do not change meaningfully (Table 1).

Table 1. Dominant motives among students.

\begin{tabular}{|l|l|l|}
\hline \multicolumn{1}{|c|}{ Career motive } & \multicolumn{1}{|c|}{ Studying motive } & \multicolumn{1}{|c|}{ Life motive } \\
\hline \multicolumn{2}{|c|}{ Students of courses 1-2 in 2018 } \\
\hline $\begin{array}{l}\text { Serving } \\
\text { Integration of lifestyles } \\
\text { Self-reliance }\end{array}$ & Creative activity & Human stupidity \\
\hline \multicolumn{2}{|c|}{ Students of courses 3-4 in 2020 } \\
\hline $\begin{array}{l}\text { Serving } \\
\text { Integration of lifestyles }\end{array}$ & Creative activity & $\begin{array}{l}\text { Human stupidity } \\
\text { Addictions }\end{array}$ \\
\hline
\end{tabular}

If in the first two courses, the dominant career motives of female students were "Serving", "Integration of lifestyles" and "Self-reliance", then in the last two courses, the career motive "Self-reliance" is no longer the leading one. In other words, by the end of the bachelor's education, the leading career orientation of female students, associated with striving for independence, free career decisions, is reduced, while the priority of striving to work with persons and to balance various aspects of own life (family, work, selfdevelopment) is retained in all courses of study as a leading career orientation. When explaining this part of the results, one can agree with the point of view of the researchers that the career motives "Serving" and "Integration of lifestyles" are substantively consistent with the specifics of humanitarian professions and, in particular, with the psychologist's profession $[16,19]$.

However, the reduction of the career motive "Self-reliance" by the end of bachelor studies may be an indicator of a decrease in the motivational potential of self-sufficiency and independence in solving career issues. And this happens at the time of a change in the social situation of the subject's development, when a transition to the search for a real place of work and its implementation is required.

Let us turn to the analysis of the results associated with the expansion of the list of leading life motives among students of the last years of study due to the "addition" of the motive "Addictions" to the motive "Human stupidity". If the motive "Human stupidity" reflects striving of the subject for self-assertion through knowledge, then the motive "Addictions" reflects striving of the subject to relieve tension. Taking into account the assumption that the first motive is based on the needs of the individual, and the second one - on the needs of the biological individual [25], one can say that by the study end, female students are dominated by life motives that are not substantively based on the needs of a social individual or subject of activity, which consist in the need to rely on social, including social and professional standards, requirements, and models.

The indicated transformations of career and life motives from the first to the last courses of study take place against the background of the dominant educational motive "Creative activity" that is unchanged in content.

As follows from Table 2, in the first courses of study, the leading educational motive "Creative activity" is positively influenced by the intensity of both the career motive "Entrepreneurship" (leading influence) and the life motive "Addictions". In the last courses of study, the leading educational motive "Creative activity" is influenced by high manifestations of career motives "Self-reliance" (leading influence) and "Stability of the place of residence", the life motive "Money", as well as low expression of both career motives of "Management" and "Job stability", and life motives "Career"," Fashion", "Aggression-self-defense" (self-protection). 
Table 2. The influence of career and life motives on the dominant educational motive in students.

\begin{tabular}{|c|c|c|}
\hline Studying motive & Career motive & Life motive \\
\hline \multicolumn{3}{|c|}{ Students of courses 1-2 in 2018} \\
\hline $\begin{array}{l}\text { Creative activity } \\
(\mathrm{R}=0.582 ; \mathrm{p}<0.00004)\end{array}$ & $\begin{array}{l}\text { Entrepreneurship } \\
(\text { beta }=+0.572 ; p<0.000039)\end{array}$ & $\begin{array}{l}\text { Addictions } \\
(\text { beta }=+0.298 ; \mathrm{p}<0.014)\end{array}$ \\
\hline \multicolumn{3}{|c|}{ Students of courses 3-4 in 2020} \\
\hline $\begin{array}{l}\text { Creative activity } \\
(\mathrm{R}=0.582 ; \mathrm{p}<0.00004)\end{array}$ & $\begin{array}{l}\text { Management } \\
(\text { beta }=-0.367 ; \mathrm{p}<0.036) \\
\text { Self-reliance } \\
(\text { beta }=+0.479 ; \mathrm{p}<0.0093) \\
\text { Stability of work } \\
(\text { beta }=-0.387 ; \mathrm{p}<0.016) \\
\text { Stability of the place of residence } \\
(\text { beta }=+0.268 ; \mathrm{p}<0.048)\end{array}$ & $\begin{array}{l}\text { Aggression-self-defense } \\
(\text { beta= }-0.258 ; \mathrm{p}<0.048) \\
\text { Money } \\
(\text { beta= }+0.269 ; \mathrm{p}<0.05) \\
\text { Fashion } \\
(\text { beta }=-0.301 ; \mathrm{p}<0.033) \\
\text { Career } \\
(\text { beta= }-0.243 ; \mathrm{p}<0.051)\end{array}$ \\
\hline
\end{tabular}

In other words, in the first years of study, striving for creative activity in the assimilation of professional knowledge is supported, to a greater extent, by the expressed desire of students to build a career related to working for themselves, and to a lesser extent, by striving to build a life without stress. In the last courses of study, striving for creative activity in the assimilation of professional knowledge is supported, to a greater extent, by the expressed desire to build a career associated with independence in making career decisions, safety and stability of the place of residence, and the desire for a materially secure life.

Thus, with the acquisition of professional education, the range of leading career and life motives, as well as the structure of motives of female students in psychology, are transformed: from the unambiguous influence on the educational motive of career and life motives in the first courses of study to a branched structure and ambiguous influence on the educational motive of a number of career and life motives in the last courses of study. In the first years of female students' education, their educational motive "Creative activity" is supported by two motives, one of which is of career ("Entrepreneurship"), and the other one is of life ("Addictions"). In the last courses of study of female students, their educational motive "Creative activity" is experiencing not only a supporting influence on the part of career ("Self-reliance", "Stability of the place of residence") and life ("Money") motives but also a weakening influence on the part of a number of career ("Management", "Job stability") and life ("Aggression-self-defense", "Fashion", Career) motives.

\section{Conclusions}

The female students in psychology showed the dynamics of their motives from the initial to the last courses of professional education at the university. This is manifested in changing the range of leading career and life motives, as well as in the transformation of the influence of career and life motives on the educational motive.

As female students in psychology grow up professionally, the range of their dominant career and life motives changes: the list of the former ones is narrowing, and the list of the latter ones is expanding. The leading educational motives relating to the Creative activity do not change meaningfully.

While obtaining professional education at the university, the structure of motives of female students in psychology is transformed: from the unambiguous influence on the educational motive of career and life motives in the first courses of study to a branched structure and ambiguous influence on the educational motive of a number of career and life motives in the last courses of study. 
As a result of the research, the content of the leading educational, career and life motives of female students in psychology at different courses of study at the university was revealed. The dynamics of educational, career and life motives of female students in psychology has been established, which manifests itself in the learning process in changing the range of leading career and life motives, as well as in the transformation of the educational, career and life motives structure.

\section{References}

1. R.E. Kodermyatov, N.A. Tumakova, A.E. Senczov, E.V. Pavlovskaya, On the problem of psychological and pedagogical support of the educational process, Young scientist, 11(91), 1738-1740 (2015)

2. E.I. Pilyugina, O.V. Berezhnova, Psychological support of personal and professional development of a university student, Young scientist, 10(45), 289-291 (2012)

3. E.S. Onishhenko, Psychological support of students of higher educational institutions [Electronic resource] https://nsportal.ru/vuz/psikhologicheskienauki/library/2014/08/06/psikhologicheskoe-soprovozhdenie-studentov-vysshikh (2014)

4. S.V. Velieva, N.A. Mashkin, E.R. Khairullina, T.N. Semenova, M.E. Varlamova, T.S. Guseva, M.V. Dolgasheva, University student professional selfactualization: Context of personality subjectivity, Espacios, 39 (20), 12 (2018)

5. V.A. Fedotova, S.Y. Zhdanova, Adaptation of students from India and Arab countries to the educational context of institutions of higher education in Russia, Social psychology and society, 11(2), 93-106 (2020)

6. I. Ishmuhametovs, L. Kuzmenko, A. Palma, Conditions for Foreign Students' Adaptation and Its Characteristic Features in the Higher Education Institution in Latvia, Lecture notes in networks and systems, 117, 694-704 (2020)

7. L.A. Apanasyuk, E.V. Smirnova, R.H. Mukhutdinov, A. Maseleno, The problem of the organization of socio-cultural environment for adaptation and development of astudent-migrant's bilingual identity in the conditions of the Russian higher education, International journal of recent technology and engineering, 7(6), 5865 (2019)

8. A.A. Utyuganov, The system of value-semantic orientations of cadets of universities of the National Guard: phenomenology and psychological and pedagogical determinants of formation, 401 (Kemerovo, 2019)

9. M. Plevnik, K. Babnik, Learning styles and preferences for future professional work among undergraduate kinesiology students , Journal of elementary education, 13, 81$104(2020)$

10. E.P. Komarova, O.P. Poluhina, S.A. Bakleneva, A.S. Fetisov, Psychological and pedagogical basis of the model forming a professional personal position of a studentpsychologist at a university, Yazyk i kultura-language and culture, 50, 196-207 (2020)

11. I.I. Khasanova, I.E. Zavadskaya, Development of key competencies of students based on social and professional values, Professional education. Capital, 1, 14-15 (2008)

12. S.A. Pfetcer, A.A. Zelenin, M.S. Yaniczkij, Political participation and political values of the youth of the Russian province, 143 (Novosibirsk: SB RAS Publishing House, 2014)

13. S. Ardenghi, M. Luciani, G. Rampoldi, D. Ausili, M. Bani, S. Di Mauro, M.G. 
Strepparava, Personal values among first-year medical and nursing students: A crosssectional comparative study, Nurse Education Today, 100, 104827 (2021)

14. N.P. Koptseva, World outlook of university students: Analysis of students' values in the Siberian Federal District (the Russian Federation), Science for Education Today, 10(6), 101-119 (2020)

15. E.A. Lezhneva, The motive for achieving success in the structure of professional motivation of the future psychologist as an indicator of career orientations, Humanities and education, 4(12), 56-59 (2012)

16. A.M. Sheveleva, Career orientations of psychology students in combination with academic and work motives, [Electronic resource] https://mirnauki.com/PDF/74PSMN519.pdf (2019)

17. Yu.E. Vodyaxa, E.A. Maksimova, A.V. Smirnov, Psychological diagnostics of personality spheres, [Electronic resource] https://docviewer.yandex.ru/view/84275520/ (2018)

18. N. Hesse, J. Brunjes, How entrepreneurial are students who intend to become academics? - A study of career motives, Review of regional research, 38(1), 27-52 (2018)

19. E.N. Polyanskaya, Career orientations of modern Russian youth, Modern problems of science and education, 2, 589 (2014)

20. A.K. Markova, T.A. Matis, A.B. Orlov, Building Learning Motivation, 192 (Moscow: Prosveshhenie, 1990)

21. V.R. Petrosyancz, A.M. Selivanova, The structure of educational and professional motivation of students - future psychologists, Young scientist, 7(141), 560-562 (2017)

22. K.A. Abulhanova-Slavskaya, Life strategy, 229 (Moscow: Mysl, 1991)

23. S.T. Dzhaneryan, Professional Self-Concept: System Analysis, 480 (Rostov-on-Don: Rostov university publishing house, 2004)

24. T.N. Vasilyeva, T.A. Fokina, O.V. Golubeva, M.V. Muxina, On the professional preferences of psychology students in different admission years, [Electronic resource] http://mir-nauki.com/PDF/62PSMN516.pdf (2016)

25. A.A. Bodalev, V.V. Stolin, General psychodiagnostics, 210-215 (St. Petersburg: Publishing house "Rech", 2000) 